\title{
Effects of Prenatal Terbutaline Exposure on Cellular Development in Lung and Liver of Neonatal Rat: Ornithine Decarboxylase Activity and Macromolecules
}

\author{
E. M. KUDLACZ, H. A. NAVARRO, J. P. EYLERS, S. E. LAPPI, S. S. DOBBINS, AND \\ T. A. SLOTKIN \\ Department of Pharmacology, Duke University Medical Center, Durham, North Carolina 27710
}

\begin{abstract}
Endogenous $\beta$-adrenergic input has been hypothesized to control patterns of cellular maturation in sympathetic target tissues by providing a timing signal for patterns of cell replication, differentiation, and responsiveness. In the current study, we examined the consequences of fetal exposure to a $\beta$-agonist, terbutaline $(2 \mathrm{or} 10 \mathrm{mg} /$ $\mathrm{kg}$ on gestational d 17, 18, and 19), in developing rat lung and liver, as assessed with ornithine decarboxylase activity and measurements of tissue macromolecules. Drug treatment caused an acute stimulation of ornithine decarboxylase in fetal and neonatal lung and blunted the peak of enzyme activity seen at 20-30 d postnatally without affecting acute responsiveness to $\beta$-adrenergic stimulation (isoproterenol). Consistent with these results, patterns of cell replication and differentiation were altered, characterized by a deficit in cell acquisition (DNA content); in the tissue displaying fetal ODC stimulation (lung), there was also evidence for developmental abnormalities in RNA and protein. Thus, by prematurely stimulating $\beta$-adrenergic receptors, prenatal administration of adrenergic agonists may have long-lasting, adverse effects on tissue development and responsiveness. (Pediatr Res 25:617-622, 1989)
\end{abstract}

\section{Abbreviations}

ODC, ornithine decarboxylase

$\mathrm{SC}$, subcutaneous

Biogenic amines have been shown to play a pivotal role in mammalian development. Circulating catecholamines, released from the adrenal medulla in response to the stress of birth, evoke short-term respiratory, cardiovascular and metabolic adjustments which are essential for neonatal survival in the immediate perinatal period $(1,2)$. We have recently shown that, in the fetal rat, lung $\beta$-adrenergic receptors become coupled to reabsorption of lung liquid and to regulation of phosphatidic acid phosphatase (a key enzyme in surfactant synthesis) just before birth (3). Importantly, the ability of $\beta$-receptors to evoke these responses then declines after birth even though receptor binding sites increase $(3,4)$, suggesting that the linkage of receptors to specific cellular events may be relatively more critical to development than is the absolute number of receptors.

The onset of noradrenergic neuronal function represents an-

Received December 7, 1988; accepted February 23, 1989.

Correspondence Dr. T. A. Slotkin, Box 3813, Duke University Medical Center, Durham, NC 27710

Supported by USPHS Grant HD-09713. other phase in which transient coupling of $\beta$-receptors to a specified response is important. Development of sympathetic synaptic competence and cardiovascular reflex function is accompanied by a surge in sympathetic tone which is most notable in the second to fourth postnatal wk in the rat $(5,6)$. During this period, sympathetic input has been proposed to serve as a "switch" that reduces or terminates cell replication in favor of differentiation and cell enlargement $(4,7)$. Indeed, at this point, $\beta$-receptors become highly coupled to the ability to shut off DNA synthesis in peripheral tissues, a function that is subsequently lost (4). Concurrently, the ability of receptor activation to stimulate ODC becomes favored $(3,8,9)$. ODC initiates the synthesis of polyamines, intracellular regulators of macromolecule synthesis $(10,11)$ : trophic hormones (including catecholamines) typically induce ODC as a prelude to enhancing RNA and protein synthesis (9-12).

In our earlier work with developing lung, we found that the ability of $\beta$-receptors to stimulate ODC, although detectable in the fetus, was relatively low, a factor which would tend to protect lung replication/differentiation patterns from short-term effects of the catecholamines released acutely at birth (1-4). However, at the same time, the presence of that small degree of reactivity also suggested that repeated, intense $\beta$-adrenergic stimulation could affect cellular development, a common situation when $\beta$ agonists, such as terbutaline, are used to arrest premature labor or to manage asthma. Accordingly, in the current study, we have examined the effects of late gestational treatment with terbutaline on cellular development in fetal and neonatal rat lung as well as liver, a tissue that also possesses $\beta$-receptors coupled to ODC but that undergoes high rates of cell replication much later in development. In addition to evaluating the immediate impact of drug treatment on basal tissue ODC activity, we have examined the subsequent effects on the linkage of $\beta$-receptors to ODC, and perhaps more importantly, on patterns of cell replication and differentiation (DNA, RNA, and protein).

\section{MATERIALS AND METHODS}

Timed pregnant Sprague Dawley rats (Zivic-Miller Laboratories, Allison Park, PA) were housed individually and given food and water ad libitum. On gestational d 17, 18, and 19, dams were given terbutaline (Geigy Pharmaceuticals, Ardsley, NY) at a dose of either $2 \mathrm{mg} / \mathrm{kg}$ or $10 \mathrm{mg} / \mathrm{kg} \mathrm{SC}$; controls received equivalent vol of saline. For prenatal studies, dams were killed by decapitation $24 \mathrm{~h}$ after the last dose, three fetuses were excised from each, and their tissues were pooled for analysis. After birth, pups were randomized and redistributed to the nursing dams with litter size maintained at 8-12 pups; randomization was carried out again just before each experiment, and, in addition, 
pups were selected from different cages and sex-matched between treatment groups. Pups were killed by decapitation, and analyses were carried out on tissues from individual animals.

All tissues were homogenized (Polytron) in 19 vol of Tris- $\mathrm{HCl}$ buffer ( $\mathrm{pH} 7.2$ ), and aliquots were taken for the various assays. ODC activity was measured in the $26000 \times g$ supernatant solution by the method of Bartolome and Slotkin (13) at a final substrate concentration of $4 \mu \mathrm{M}$ L-ornithine- $\left[1-{ }^{14} \mathrm{C}\right]$ (New England Nuclear Corp., Boston, MA; sp act $53.1 \mathrm{mCi} / \mathrm{mmol}$ ) in the presence of $50 \mu \mathrm{M}$ pyridoxal-5'-phosphate and 1.5-mM dithiothreitol. Because acute or long-term changes in ODC activity can include induction, activation or other posttranslational modifications of the enzyme (13), we selected a subsaturating concentration of ornithine so as to enable detection of alterations regardless of the specific kinetic mechanism involved.

In another aliquot, extraction and analysis of DNA, RNA, and protein were carried out by standard procedures $(14,15)$. Results of the macromolecule determinations were evaluated both as concentration ( $\mathrm{mg} / \mathrm{g}$ tissue) and content (mg/tissue). These can have distinctly different meanings: for example, DNA concentration gives a measure of cell packing density, whereas DNA content assesses the total number of cells present within the specified tissue. We also used the measurements of macromolecule concentration to calculate the protein/DNA ratio, a biochemical index of relative cell size $(14,16)$.

In addition to studies of basal developmental characteristics, ODC responses to acute $\beta$-adrenergic agonist challenge were evaluated. Animals in control and terbutaline groups were given D,L-isoproterenol sulfate $(2.5 \mathrm{mg} / \mathrm{kg} \mathrm{SC}$; Sigma Chemical Co., St. Louis, MO) or an equivalent vol ( $1 \mu \mathrm{L} / \mathrm{g}$ body wt $)$ of vehicle and killed $4 \mathrm{~h}$ later, a dose and time span previously shown to be optimal for observing $\beta$-agonist-induced increases in ODC activity $(8,17)$. Stimulation of ODC was then evaluated as the difference between values in the isoproterenol group and its corresponding saline cohort.

Data analysis and statistics. Data are presented as means and SEM. For the prenatal data, fetuses of each dam were considered to represent a single determination; thus " 10 prenatal determinations" would denote fetuses analyzed from 10 different dams. For postnatal studies, the indicated number of determinations represents individual animals, which is appropriate because of the randomization procedure used after birth. Initial statistical analyses were conducted by ANOVA (data log-transformed whenever variance was heterogeneous). Longitudinal differences in tissue wt, macromolecules, and basal ODC activity were evaluated by 2-way ANOVA with factors of age and terbutaline treatment. Evaluation of acute responses to isoproterenol was carried out by 3-way ANOVA (age, terbutaline treatment, isoproterenol treatment), followed by appropriate lower-order ANOVA where interactions of terbutaline $x$ isoproterenol treatment or terbutaline $\times$ isoproterenol $\times$ age were found. Individual ages at which differences between control and terbutaline groups were significant were then evaluated post hoc by Duncan's multiple range test. Significance was assumed at the level of $p<0.05$. For convenience, body and tissue wt, and macromolecule concentration and content are all presented as percentages of control values; however, statistical analyses were performed only on the raw data.

\section{RESULTS}

Maternal terbutaline treatment on gestational d 17, 18, and 19 did not affect maternal wt gain, number of fetuses/dam (measured on gestational d 20) or the number of pups per litter at birth (Table 1). Dams in all three treatment groups gave birth on the $22 \mathrm{nd} d$ of gestation. Postnatal wt gains in the pups were within normal limits in the $2 \mathrm{mg} / \mathrm{kg}$ group but did show a small initial retardation in animals exposed to the higher dose (Fig. 1). All wt differences disappeared by the end of the second postnatal wk.
Table 1. Maternal wt gain and delivery characteristics*

\begin{tabular}{|c|c|c|c|}
\hline Treament & $\begin{array}{c}\text { Maternal wt gain } \\
\text { ( } \Delta \mathrm{g} \text { from } \\
\text { GD17-21) }\end{array}$ & $\begin{array}{c}\text { Fetuses/dam } \\
\text { (GD20) }\end{array}$ & $\begin{array}{c}\text { Pups/litter } \\
\text { (at birth) }\end{array}$ \\
\hline & $64 \pm 10$ & 13.8 & $12.6 \pm 0.6$ \\
\hline Terbutalin & $70 \pm$ & $13.3 \pm$ & $13.8 \pm 0.6$ \\
\hline Terbutaline $(10 \mathrm{mg} / \mathrm{kg})$ & $61 \pm 10$ & $14.6 \pm 0.4$ & $13.1 \pm 0.7$ \\
\hline
\end{tabular}

* Data represent means \pm SEM of values from 11-16 dams in each treatment group. Terbutaline was given at the indicated doses on gestational d (GD) 17,18 , and 19. Every dam in each treatment group gave birth on the 22 nd $d$ of gestation.

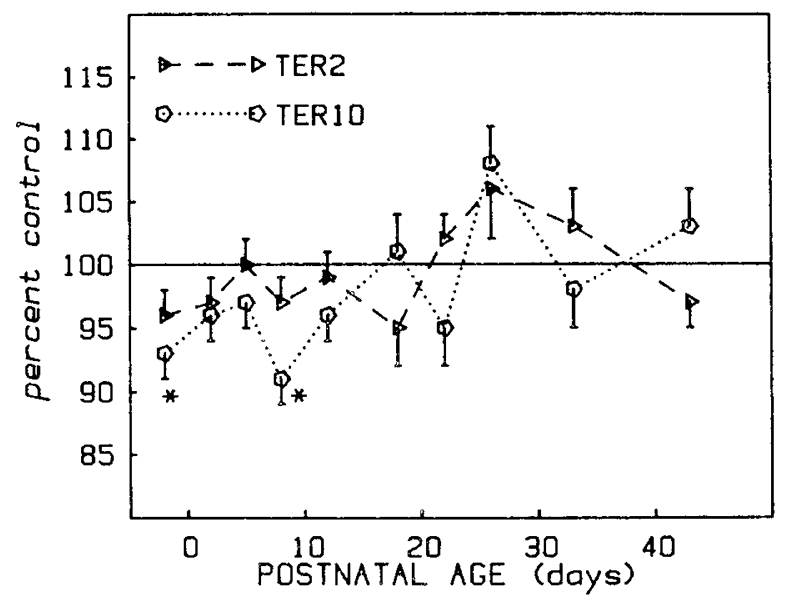

Fig. 1. Effects of terbutaline treatment on gestational d 17, 18, and 19 on body wt of fetuses and neonates. TER $2=2 \mathrm{mg} / \mathrm{kg} \mathrm{SC}$; TER $10=$ $10 \mathrm{mg} / \mathrm{kg}$ SC. Data represent means and SEM of values obtained from 11 to 40 rats in each treatment group at each age. ANOVA indicates a reduction in body wt only at the higher dose of terbutaline (main treatment effect and interaction of treatment $\times$ age). ${ }^{*}$, individual ages at which the TER 10 group differs significantly from controls. Control body wt averaged $0.38 \mathrm{~g} 2 \mathrm{~d}$ before birth, $8.9 \mathrm{~g}$ on postnatal $\mathrm{d} 2,14.1 \mathrm{~g}$ on $\mathrm{d} 4,22.6 \mathrm{~g}$ on $\mathrm{d} 8,34.5 \mathrm{~g}$ on $\mathrm{d} 12,49 \mathrm{~g}$ on $\mathrm{d} 18,68 \mathrm{~g}$ on $\mathrm{d} 22,83 \mathrm{~g}$ on $\mathrm{d} 26,143 \mathrm{~g}$ on $\mathrm{d} 33$, and $217 \mathrm{~g}$ on $\mathrm{d} 43(\mathrm{SEM}<4 \%)$.

Basal ODC activity and acute responses to isoproterenol. In keeping with earlier results $(17,18)$, the developmental pattern of basal lung ODC in the control group displayed three characteristic phases (Fig. 2, left). Before birth, ODC was high and then declined sharply in the immediate postnatal period. A small increase was observed during the first postnatal wk and a subsequent, larger peak of activity was evident in the 4th wk. This pattern was significantly affected by maternal terbutaline treatment: on gestational d 20 ( $24 \mathrm{~h}$ after the last terbutaline dose), activity was profoundly elevated in a dose-dependent manner, an effect which persisted into the immediate postnatal period. Prenatal terbutaline exposure also altered the later phase of rise of basal ODC, with a shift toward earlier appearance of the peak of activity ( $2 \mathrm{mg} / \mathrm{kg}$ group) and a blunting of the magnitude of the peak (both doses, but most prominently at $10 \mathrm{mg} / \mathrm{kg}$ ).

Basal liver ODC showed little or no stimulation by terbutaline in the prenatal period immediately following drug exposure (Fig. 2 , right). However, as in the lung, the terbutaline groups displayed a premature, attenuated peak of liver enzyme activity during the 4 th postnatal wk.

In control rats, responsiveness of ODC to acute challenge with isoproterenol was low at birth and rose to a maximum during the 4th postnatal wk in both lung (Fig. 3, left) and liver (Fig. 3, right). Animals exposed prenatally to terbutaline also displayed a peak of isoproterenol stimulation during the 4th wk. However, the treated group tended to exhibit elevated responses later on (d 43 in lung, d 33 and 43 in liver). 
Tissue growth and macromolecules. In control rats, the period of greatest cell proliferation in the postnatal lung occurred during the first 2 postnatal wk and was characterized by rapid increases in DNA, RNA, and protein content (Fig. 4, left). The subsequent cessation of cell acquisition and maintenance of tissue growth by cell enlargement was apparent by decreases in DNA concentration during the 4th postnatal wk. In contrast to the developing lung, liver DNA, RNA, and protein levels showed their most dramatic increase during the third and fourth postnatal wk (Fig. 4, right).

As prenatal terbutaline exposure at $2 \mathrm{mg} / \mathrm{kg}$ significantly altered the developmental pattern of ODC without affecting body wt, we examined lung and liver nucleic acids and proteins at this dose. Initially, maternal terbutaline treatment caused a significant elevation in neonatal lung RNA, despite the presence of reductions in lung wt and protein (Fig. 5, left). Subsequently, the terbutaline group exhibited deficiencies in total cell numbers (DNA content) and packing density (DNA concentration), accompanied by corresponding deficits of other macromolecules. In the liver, terbutaline exposure failed to cause an initial elevation in RNA and had a smaller effect (not statistically significant) on growth and protein levels (Fig. 5, right). Nevertheless, these animals developed a significant deficit in DNA and a corresponding shortfall in RNA.
BASAL LUNG ODC ACTIVITY

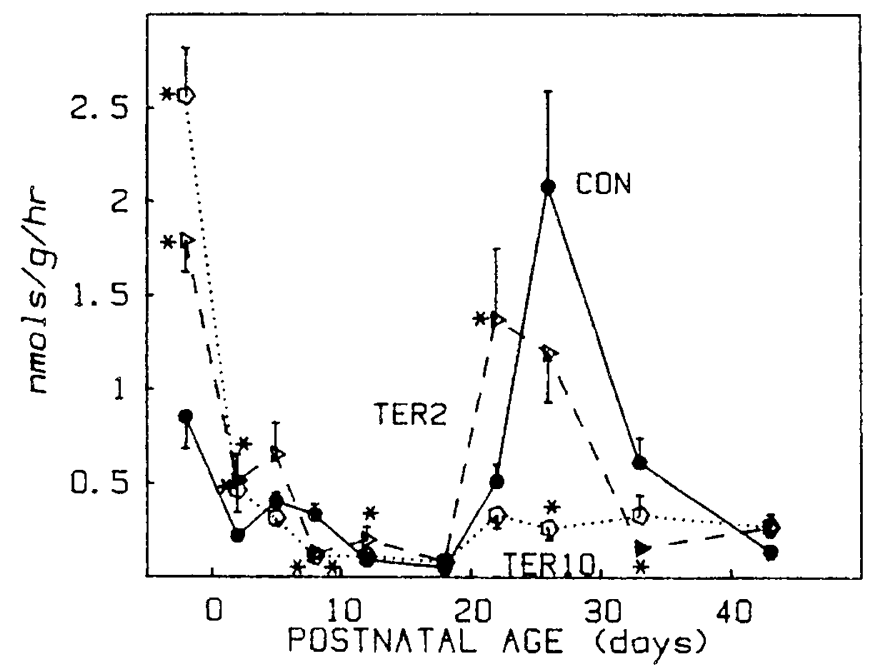

BASAL LIVER ODC ACTIVITY

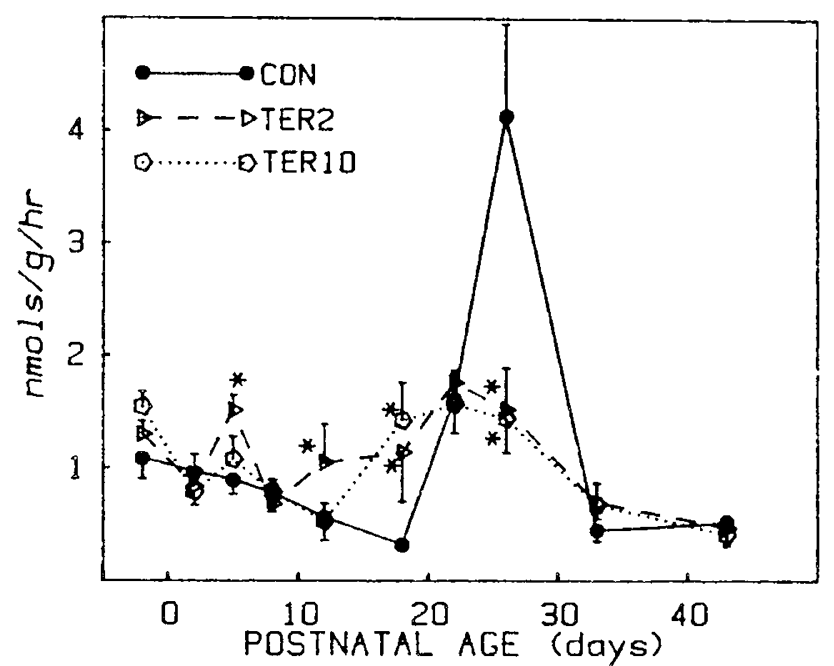

Fig. 2. Effects of prenatal terbutaline administration on basal ODC activity in developing lung (left) and liver (right), CON = control group; TER2 $=$ terbutaline, $2 \mathrm{mg} / \mathrm{kg}$; TER $10=$ terbutaline, $10 \mathrm{mg} / \mathrm{kg}$. Data represent means and SEM of values from $7-28$ rats in each treatment group at each age. ANOVA indicates significant effects of terbutaline in either tissue at both dosage levels (lung, interaction of treatment $\times$ age at $2 \mathrm{mg} /$ $\mathrm{kg}$, main treatment effect and interaction of treatment $\times$ age at $10 \mathrm{mg} / \mathrm{kg}$; liver, main treatment effect, and interaction of treatment $\times$ age at either dose). $*$, individual ages at which the terbutaline groups differ significantly from controls.

ISOPROTERENOL STIMULATION

OF LUNG ODC ACTIVITY

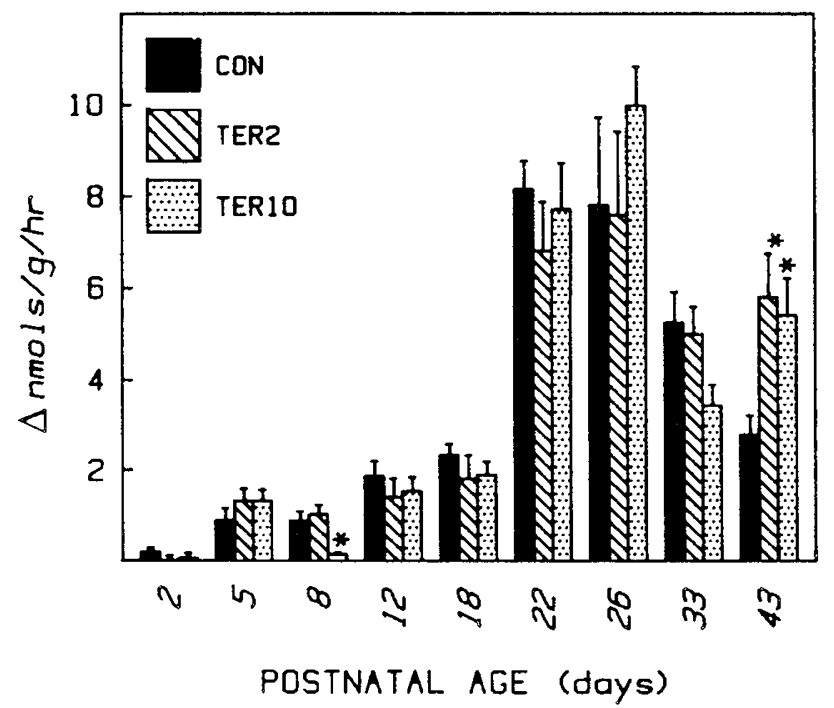

ISOPROTERENOL STIMULATION

OF LIVER ODC ACTIVITY

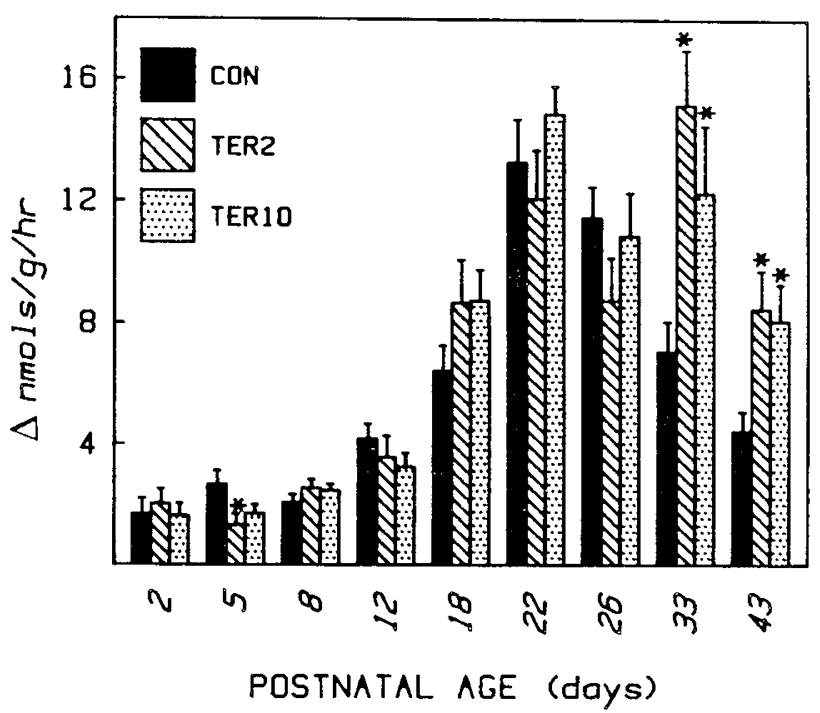

Fig. 3. Effects of prenatal terbutaline administration on the acute stimulatory response of ODC to $\beta$-adrenergic agonist stimulation (isoproterenol, $2.5 \mathrm{mg} / \mathrm{kg}$ ). CON = control group; TER2 = terbutaline, $2 \mathrm{mg} / \mathrm{kg}$; TER $10=$ terbutaline, $10 \mathrm{mg} / \mathrm{kg}$. Basal (unstimulated) values appear in Figure 2 . Data represent means and SEM of stimulations evaluated in eight-28 rats in each treatment group at each age. In both lung (left) and liver (right), ANOVA indicates significant effects of terbutaline at either dosage level (lung, treatment $\times$ age interaction at either dose; liver, treatment $\times$ age interaction at $2 \mathrm{mg} / \mathrm{kg}$, main treatment effect at $10 \mathrm{mg} / \mathrm{kg}$ ). *, individual ages at which the terbutaline groups differ significantly from controls. 

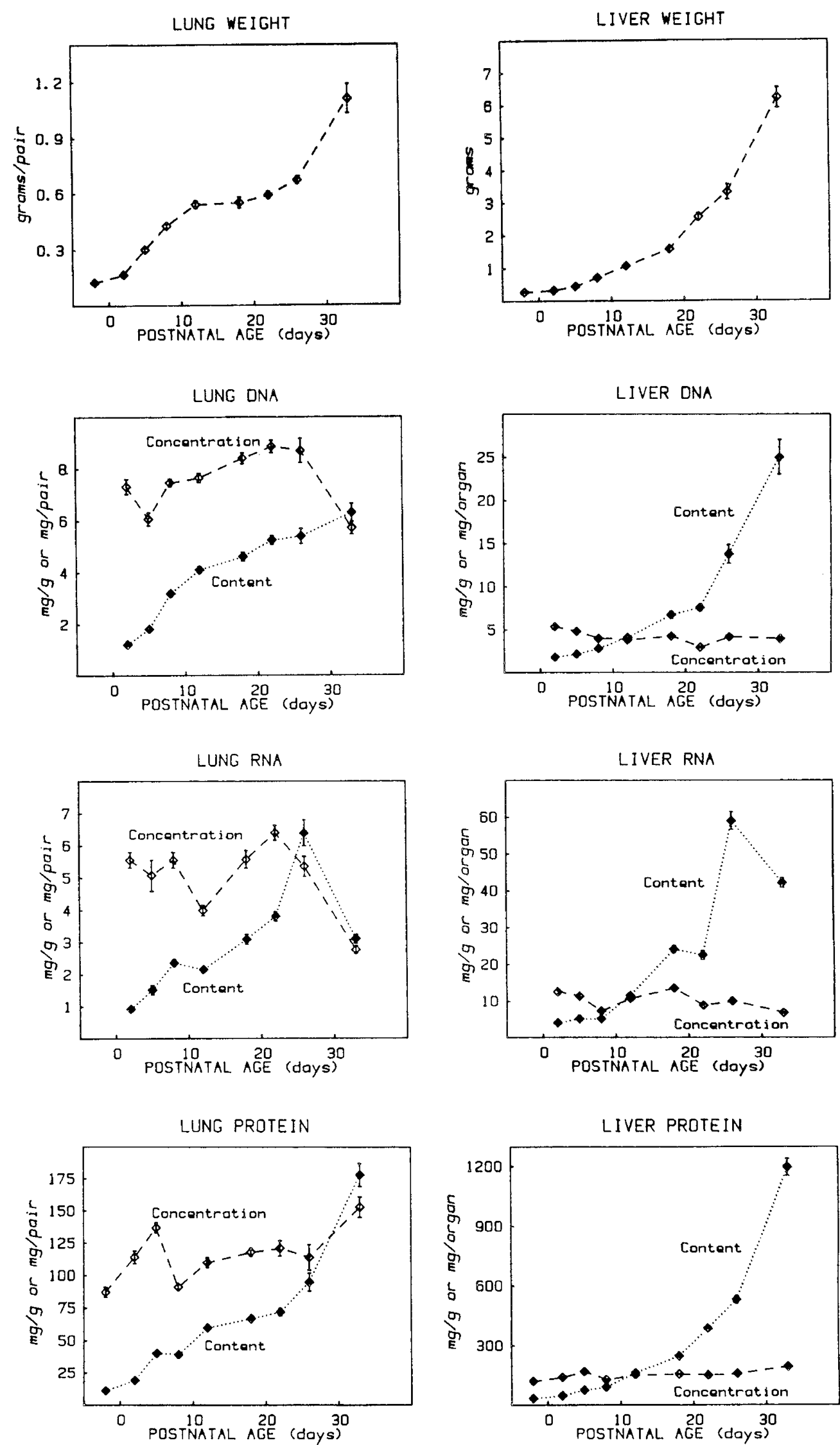

Fig. 4. Developmental profile of tissue weights and macromolecules in control rats. The latter are presented both as concentration (mg/g tissue) and content (mg in a pair of lungs or in a liver). Data represent means and SEM of values from eight to 10 rats at each age. 

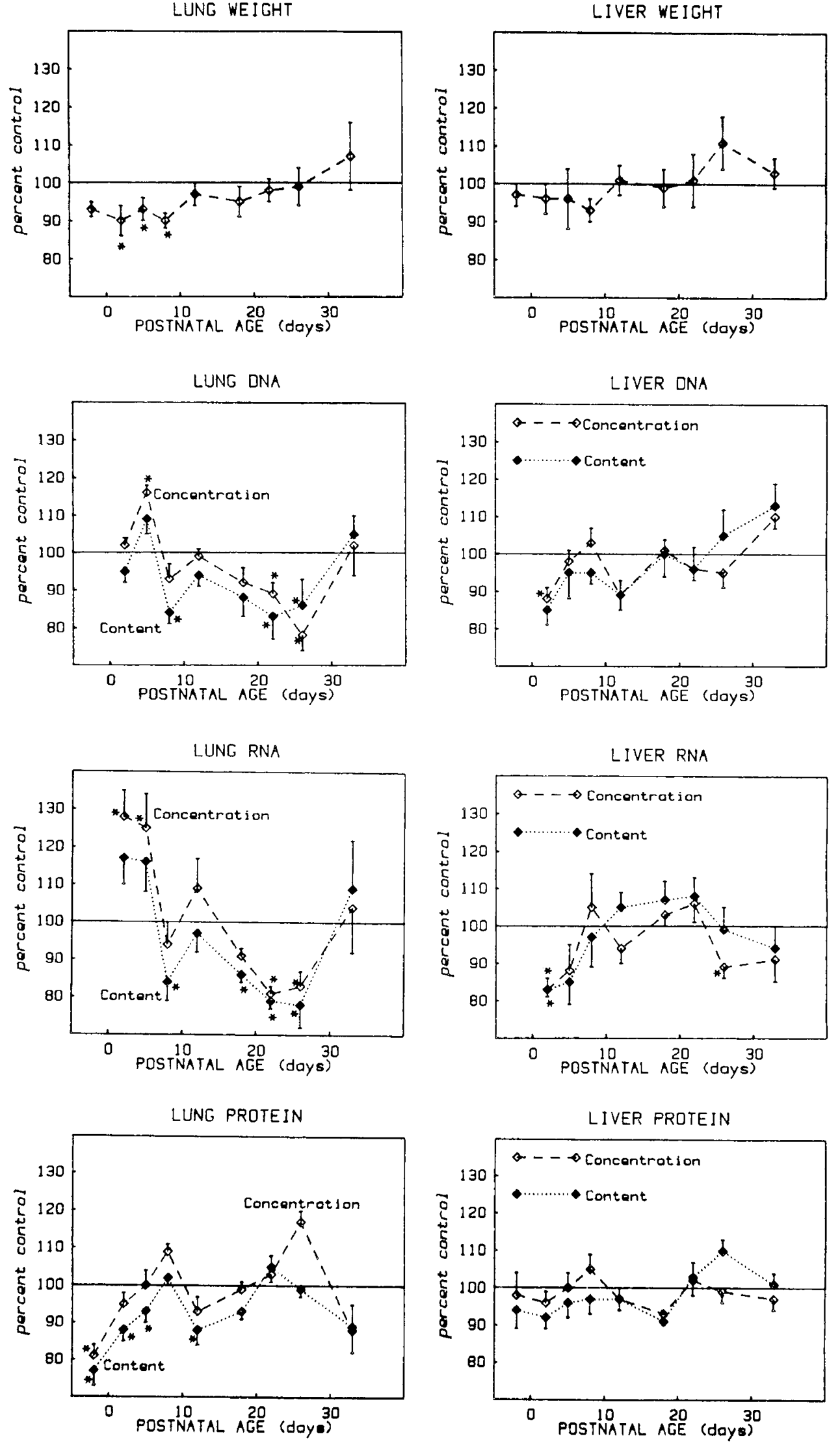

Fig. 5. Effects of prenatal terbutaline administration $(2 \mathrm{mg} / \mathrm{kg})$ on tissue wt and macromolecules, presented as a percentage of the control values in Figure 4. Data represent means and SEM of values from eight-10 rats at each age. For lung, ANOVA indicates a significant reduction in wt (main treatment effect), a deficit in DNA content and concentration (main treatment effect and treatment $\times$ age interaction), alterations in RNA content and concentration (treatment $\times$ age interaction) and in protein concentration (treatment $\times$ age interaction), and an overall lowering of protein content (main treatment effect and treatment $\times$ age interaction). There were no statisticaliy significant effects on liver wt or DNA content, but DNA concentration was affected (treatment $x$ age interaction). Liver RNA concentration (main treatment effect) and content (main treatment effect and treatment $\times$ age interaction) were also affected by terbutaline exposure. ${ }^{*}$, individual ages where differences were significant. 
Table 2. Effects of prenatal terbutaline administration on protein/DNA ratio in lung and liver*

\begin{tabular}{|c|c|c|c|c|}
\hline \multirow{2}{*}{$\begin{array}{l}\text { Postnatal } \\
\text { age (d) }\end{array}$} & \multicolumn{2}{|c|}{ Lung } & \multicolumn{2}{|c|}{ Liver } \\
\hline & $\mathrm{CON}$ & TER2 & $\mathrm{CON}$ & TER2 \\
\hline 2 & $15.8 \pm 0.9$ & $14.6 \pm 0.5$ & $26.2 \pm 0.7$ & $28.6 \pm 0.9$ \\
\hline 5 & $23.0 \pm 1.3$ & $22.6 \pm 1.5$ & $35.2 \pm 1.0$ & $35.8 \pm 1.6$ \\
\hline 8 & $12.5 \pm 0.3$ & $14.7 \pm 0.7$ & $32.2 \pm 1.2$ & $32.8 \pm 1.3$ \\
\hline 12 & $14.6 \pm 0.7$ & $13.7 \pm 0.7$ & $40.6 \pm 1.7$ & $44.9 \pm 2.3$ \\
\hline 18 & $14.2 \pm 0.4$ & $15.5 \pm 1.0$ & $36.8 \pm 1.2$ & $33.5 \pm 0.8$ \\
\hline 22 & $13.8 \pm 0.7$ & $16.0 \pm 0.8$ & $51.1 \pm 1.4$ & $54.7 \pm 2.7$ \\
\hline 26 & $17.3 \pm 1.7$ & $20.2 \pm 1.2$ & $38.4 \pm 1.5$ & $40.3 \pm 1.8$ \\
\hline 33 & $27.3 \pm 2.0$ & $24.1 \pm 2.4$ & $48.7 \pm 2.5$ & $43.7 \pm 2.0$ \\
\hline
\end{tabular}

* Data represent means and SEM of values from six to 10 rats at each age in control (CON) and $2 \mathrm{mg} / \mathrm{kg}$ terbutaline (TER2) groups. ANOVA indicates no significant treatment effect or interaction of treatment $\times$ age for either tissue.

Neither lung nor liver showed any significant effects of maternal terbutaline treatment on protein/DNA ratio (Table 2).

\section{DISCUSSION}

Results obtained in this study support the view that, even before birth, $\beta$-adrenergic input can influence cellular development and may participate in the programming of future trophic responses of sympathetic target tissues. Despite the relative inefficiency of the coupling of fetal lung $\beta$-receptors to ODC activity, repeated stimulation with terbutaline was still able to cause a profound stimulation as seen on gestational d 20. In light of the effects on ODC and the role of $\beta$-receptors in terminating cell replication (which would ordinarily occur later, with the onset of sympathetic innervation), the eventual adverse effects of terbutaline on cell acquisition (DNA) and alterations in RNA and protein may thus be viewed as a direct consequence of premature activation of lung $\beta$-receptors. The results suggest a primary effect on cell replication, i.e. no alteration of relative cell size (protein/DNA ratio) and deficits in protein levels generally matching those for DNA.

It is notable that in the liver, a tissue where ODC was not stimulated prenatally by terbutaline, deficits in DNA were substantially smaller and no promotion of RNA or deficit of protein was seen.

The rise in basal ODC activity that ordinarily occurs in lung, liver, and other peripheral tissues toward the end of the 1st mo postpartum, is thought to represent a combined trophic influence of a variety of hormonal and neuronal regulatory factors $(8,9)$. Thus, as found here, the disruption of the late peak in ODC caused by prenatal terbutaline may represent long-term interference with response capabilities of the tissue. The suppression of the peak is clearly a separable event from the direct $\beta$-receptor stimulation in the fetus, as the same late postnatal effect was seen in the liver, a tissue which did not display fetal ODC stimulation by terbutaline. Activation of the ODC pathway by neonatal neural input has been shown to be important in deter- mining future responsiveness to $\beta$-adrenergic stimulation (17), and our finding that the terbutaline-exposed animals display a late phase of enhanced responsiveness to acute isoproterenol challenge is thus consistent with this role. However, it should be noted that basal ODC was suppressed long before the alteration in the isoproterenol response, suggesting that prenatal terbutaline treatment may serve to blunt trophic effects of factors other than $\beta$-adrenergic stimulation. This possibility is undergoing active investigation in our laboratory.

\section{REFERENCES}

1. Lagercrantz H, Bistoletti P 1973 Catecholamine release in the newborn infant at birth. Pediatr Res 11:889-893

2. Slotkin TA, Seidler FJ 1988 Adrenomedullary catecholamine release in the fetus and newborn: secretory mechanisms and their role in stress and survival. J Dev Physiol 10:1-16

3. Kudlacz EM Navarro HA, Eylers JP Dobbins SS, Lappi SE Slotkin TA 1989 Sclective linkage of $\beta$-adrenergic receptors to functional responses in developing rat lung and liver: phosphatidic acid phosphatase, ornithine decarboxylase and lung liquid reabsorption. J Dev Physiol (in press)

4. Slotkin TA, Whitmore WL, Orband-Miller L, Queen KL, Haim K 1987 Betaadrenergic control of macromolecule synthesis in neonatal rat heart, kidney and lung: relationship to sympathetic neuronal development. J Pharmacol Exp Ther 243:101-109

5. Seidler FJ, Slotkin TA 1981 Development of central control of norepinephrine turnover and release in the rat heart: responses to tyramine, 2-deoxyglucose and hydralazine. Neuroscience 6:2081-2086

6. Smith PG, Slotkin TA, Mills E 1982 Development of sympathetic ganglionic neurotransmission in the neonatal rat: pre- and postganglionic nerve response to asphyxia and 2-deoxyglucose. Neuroscience 7:501-507

7. Claycomb WC 1976 Biochemical aspects of cardiac muscle cell differentiation: possible control of deoxyribonucleic acid synthesis and cell differentiation by adrenergic innervation and cyclic adenosine $3^{\prime}: 5^{\prime}$-monophosphate. $\mathrm{J} \mathrm{Biol}$ Chem 251:6082-6089

8. Grignolo A, Kuhn CM, Schanberg SM 1982 Maturation of growth hormone stimulation of kidney ornithine decarboxylase in the rat. Life Sci 30:383390

9. Bartolome J, Grignol A, Bartolome M, Trepanier P, Lerea L, Weigel S, Whitmore W, Michaiopoulos G, Kavlock R, Slotkin T 1985 Postnatal methyl mercury exposure: effects on ontogeny of renal and hepatic ornithine decarboxylase responses to trophic stimuli. Toxicol Appl Pharmacol 80:147154

10. Heby O 1981 Role of polyamines in the control of cell proliferation and differentiation. Differentiation 19:1-20

11. Slotkin TA, Bartolome J 1986 Role of ornithine decarboxylase and the polyamines in nervous system development: a review. Brain Res Bull 17:307320

12. Russell DH 1980 Ornithine decarboxylase as a biological and pharmacological tool. Pharmacology 20:117-129

13. Slotkin TA, Bartolome J 1983 Ornithine decarboxylase: marker of neuroendocrine and neurotransmitter actions. Methods Enzymol 103:590-603

14. Slotkin TA, Persons D, Slepetis RJ, Taylor D, Bartolome J 1984 Control of nucleic acid and protein synthesis in developing brain, kidney, and heart of the neonatal rat: effects of $\alpha$-difluoromethylornithine, a specific, irreversible inhibitor of ornithine decarboxylase. Teratology 30:211-224

15. Lowry OH, Rosebrough NJ, Farr AL, Randall R 1951 Protein measurement with the Folin phenol reagent. J Biol Chem 193:265-270

16. Bell JM, Whitmore WL, Queen KL, Orband-Miller L, Slotkin TA 1987 Biochemical determinants of growth sparing during neonatal nutritional deprivation or enhancement: ornithine decarboxylase, polyamines, and macromolecules in brain regions and heart. Pediatr Res 22:599-604

17. Hou Q-C, Baker FE, Seidler FJ, Bartolome M, Bartolome J, Slotkin TA 1989 Role of sympathetic neurons in development of $\beta$-adrenergic control of ornithine decarboxylase activity in peripheral tissues: effects of neonatal 6hydroxydopamine treatment. J Dev Physiol (in press)

18. Thet LA, Parra SC 1986 Role of ornithine decarboxylase and polyamines in early postnatal lung growth. J Appl Physiol 61:1661-1666 